UDC 378.096:687.01

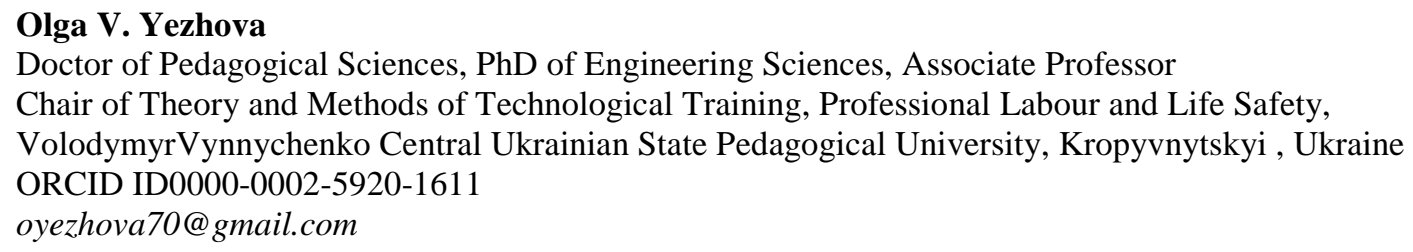

Kalina L. Pashkevich

Doctor of Engineering Sciences, Chair of Ergonomics and Fashion Designing, Professor Kyiv National University of Technologies and Design, Kyiv, Ukraine

ORCID ID 0000-0001-6760-3728

kalina.pashkevich@gmail.com

Denys V. Gryn

$\mathrm{PhD}$ of Engineering Sciences, Senior Teacher

Chair of Theory and Methods of Technological Training, Professional Labour and Life Safety

VolodymyrVynnychenko Central Ukrainian State Pedagogical University, Kropyvnytskyi, Ukraine

ORCID ID 0000-0002-5625-7812

dvgrinj@gmail.com

\title{
DEVELOPMENT OF TECHNOLOGY EDUCATION STUDENTS' ICT COMPETENCE WHILE TEACHING COMPUTER-AIDED FASHION DESIGN
}

\begin{abstract}
The present paper deals with the problem of CAD (computer-aided design) competence formation of would-be teachers of technology and vocational school teachers. It is noted that for fashion industry to develop, it is necessary that its professionals should have both the knowledge of basic communication technologies and foundations of using CAD. ICT competence is necessary for trainee teachers of technology and vocational education specialists both for their educational activity and for successful creation of outfit models using computer techniques. The aim of the research lies in grounding the list of software equipment to be used by trainee teachers of technology and vocational school teachers to provide effective learning of CAD in professional sphere. The introduction to professional-oriented software is realized in higher education institutions of Ukraine during the course of "Basics of computer aided design", after a preparatory course "Information Technologies"

Information technologies are used in fashion industry for creating new models, equipment management, and for maintaining the life cycle of outfits. Hereby presented is a systemized list of computer software tools for professional purposes to be used in automated workstation of the designer: software tools for correct and safe system component management; software for file creation and information sharing; CAD-subsystems. The content of the course "Basics of computer aided design" have been described. Practical approbation has proved effectiveness of the developed syllabus along with the methodological support of the course "Basics of computer-aided design". The results of the investigation are important for grounding the content of study for trainee teachers of technology and specialists of vocational education, as well as for professionals in fashion industry.
\end{abstract}

Keywords: CAD; ICT competence; software; design; fashion industry; education.

\section{INTRODUCTION}

The problem statement. In order to stay competent in a global world market modern fashion enterprises should produce goods of high quality, with low costs of production, in a short period of time. To reach this aim such capacities of computer technology as its memory and its ability to transmit great amounts of information are used.

Due to the use of computers for the purposes of design programming and production, the processes of enterprise management and marketing are easily automated and 
comprehensively handled. Leading enterprises of fashion industry today are equipped with the systems of computer aided design (CAD). And the majority of medium-sized and small fashion enterprises are actively investigating and introducing CAD into their production. Correspondently, students of fashion design will work at working places equipped with computerized facilities.

A topical aim of institutions of fashion education is educating highly professional and competitive specialists. And only highly professional teachers of technologies and vocational education should be involved in the study process to reach this aim and form fashion students' skill to use ICT in the professional sphere. Therefore, the problem of grounding the content and practical ways of developing ICT competence of trainee teachers of technologies and specialists of vocational education represents topicality of the research.

Analysis of recent studies and publications. The problem of the content and practical ways of developing ICT competence of trainee teachers is one of the core issues among researchers.

As mentioned in [1], in the modernized world information communicative competence comes to the fore (mainly, professional-informational competence).

It finds its manifestations in a rational choice and directed use of informationcommunication technologies (ICT) in the process of active solutionof various professional tasks. We follow UNESCO recommendations as for the stages of ICT competence formation of the pre-service professional: 1) technology literacy; 2) knowledge deepening; 3) knowledge creation [2, p. 3].

In their research [3]L.Fernández-Sanz, J.Gómez-Pérez and A.CastilloMartínezsuggested the framework of ICT competence, integrating the ICT related reference schemes with the standards: ESCO, e-CF and BOK.

Lukšènienè A. et.al [4] outline the importance of developing pupils' ICT skills during technology lessons in the secondary school.

It has been stated in the article ofO. Yezhova, K. Pashkevich, and N. Manoilenko [5], that practically all leading institutions of fashion education have included in their curricula the subjects of professional software support.

In [6] the purpose and objectives of the course «Information Technologies» are substantiated, design objects in studying this courseestablished.

The problem of developing trainee teachers' ICT competence has drawn attention of many researchers. The importance of information technological skill of would-be teachers is broadly discussed in the article of G. Gorghiu, L.M. Gorghiu, and L. Pascale [7], where the authors claim that ICT enable students to acquire the necessary competences and skills required in their studies and/or for today's digital world.

In the article [8] the ICT competence is described as one of the key competences of the modern teacher, with special attention being paid to the description of the system of raising the level of its development.

Results of the empirical research tracking development of pedagogical students' ICT competence are provided in the article of F. Chen et. al [9]. The authors come to the conclusion that development of ICT competence of trainee teachers is bound to the simultaneous formation of media literacy and informational culture.

An important constituent part of ICT competence is readiness to use CAD in professional activity.

The article of K. Peter et. al [10] is devoted to the analysis of the results of pedagogical experiment in learning CAD/CAE systems. The experiment results proved the hypothesis that greater allocation of time to teaching modeling and simulation in CAD/CAE systems will positively influence students' learning achievements. 
The results of practical use of 3D CAD systems, but in a technical university, are investigated in the article ofB. Barberoet. al[11].

The research of C. Yan et. al [12] traces the development of "Standard Parts Library of Rolling Bear Based on SolidWorks" as an example to illustrate that mechanical engineering students use teamwork and collaborate to complete the standard library research and cultivate their comprehensive CAD ability in a research project.

In order to justify the constituent structure of ICT competence for trainee teachers of technologies, it is important to define the list of necessary software tools to be used in the learning process.

The article's goal. The aim of this paper is to develop a list of software tools for the designer's automatic workstation to be used in educating trainee teachers of technologies and vocational school teachers in order to enable them to use CAD in their professional activity.

The subject of the research is the formation of the ICT competence of trainee technology teachers and vocational training teachers in the study of automated clothes design.

\section{THETHEORETICAL BACKGROUNDS}

\subsection{Methodology of ICT competence formation}

Study courses "Information Technologies" and "Basics of computer aided design" play a leading role in formation of general and professional informational competence. The above mentioned courses provide a gradual step-by-step formation of professional informational competence.

The list of software analyzed in this paper addresses professional needs of fashion industry specialists as well as those of the trainee teachers of technologies.

A gradual step-by-step approach is realized by learning the course "Information technologies" first, with further introduction of students to CAD (Computer Aided Design) in the course "Basics of computer aided design".

The main aim of the course "Basics of computer aided design" is to form professional ICT-competence, enabling students to use computer technology for cutting purposes and technological projecting of fashion industry goods. The main objectives for learning the course are the following:

- to represent varieties of software tools and technical devices and means of their use for the purposes of sewing products design and production;

- to teach students to use information technologies to handle the tasks of sewing products design;

Information technologies are broadly defined as technologies of data management and processing with the help of computing equipment.

In the sewing industry information technologies are used for creating new models, managing separate kinds of equipment, and for maintaining the life cycle of the goods. industry:

The following varieties of automated management systems are used in modern sewing

- automated design systems (CAD);

- computerized and automated equipment for cutting, production and steam pressing of sewing products;

- systems of automated information collection, transformation and sharing within the sewing enterprise.

The system of computer aided design is a technically-organized system, performing automated designing. CAD includes personnel and means of design automatization, coordinating subdivisions of project organization. 
CAD needs the following levels of supporting its maintenance: organization, methodology, mathematics, information, software, technique and linguistics.

Modern fashion CAD allows fully automated creating of new models: silhouette, cutting, modelling, issuing of necessary cutting, technological and business documents.

Professional skills mentioned above, especially the ability to produce technological documents, constitute the qualification framework for fashion specialists of all levels: engineers, technicians, qualified workers etc.

That is why educators of technological sphere as well should possess skills to use CAD of clothes for their professional purposes.

Though information technologies are used at every stage of goods production cycle at the enterprise, the core module of CAD is constituted by sub-systems of pattern making and clothes modelling.

In fashion production industry the following professional systems are used:

CAD (Computer aided design) -a program set for drafting patterns, designing and, partly, for technological documentation. It is a core module of CAD of clothes.

CAM (Computer-aided manufacturing) - a system of automated planning, management, production and control of the manufacturing operations. Very often the name of CAM-systems is used to denote programs for technological preparation of manufacturing.

CAE (Computer-aided engineering) - software for engineering calculations. Some CADs (e.g., Julivi [13]) allow to define what clothes tightness is endured by a person in each concrete zone.

PDM (Product Data Management) - a system module, responsible for storing and transmitting information, permits access of the users.

\subsection{Program software for teaching fashion industry specialists}

For performing effective design of new fashion models it is necessary to create an automated workstation (AWS) for a designer. Some separate operations can be done at the automated workstation for performing layout, equipped with the same set of software. Software equipment of AWS of the designer presupposes installation of the next basic programs (Figure 1).

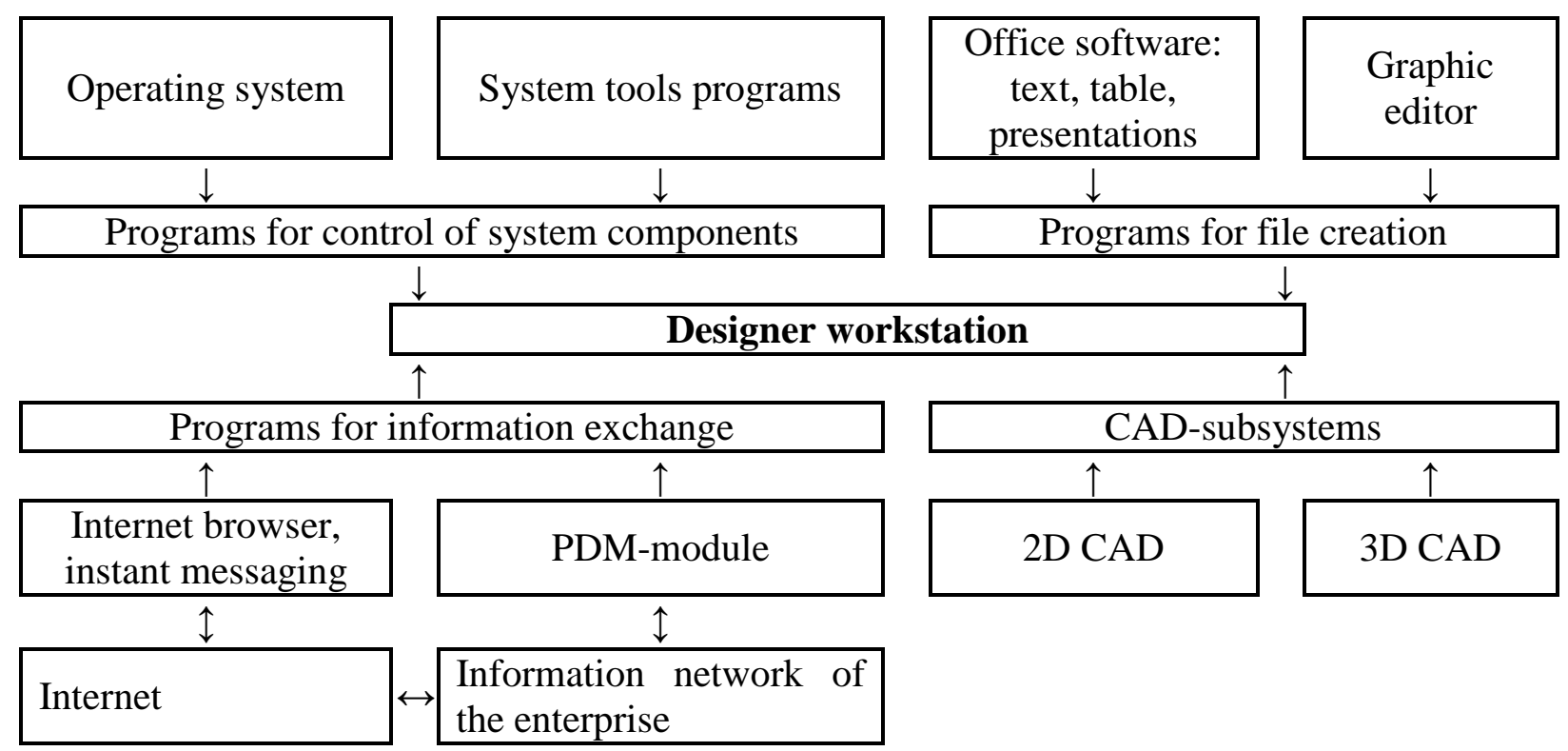

Figure1.Software equipment of an automated designer workstation 
Programs for correct and safe management of system components:operating systems for managing computer resources (e.g. Windows or Linux); system tools programs for correct and safe functioning (e.g. antivirus programs and drivers).

Programs for text/table/graph file creation. "Office" software (e.g. MS Office) is used for providing electronic file management, data base support, presentation preparation, performing calculations in the tables. Graph editors are used for creating drafts of the clothes models, embroidery and logos etc.

Programs for information exchange. PDM-module of the entire information network system of the enterprise, which includes all factory services (designers, technicians, ratesetters, economists, managers, supervisory operator etc.).

Internet browser used for Internet access and e-mail, programs for instant messaging, like Skype, ICQ and messengers.

CAD-subsystems.CAD-subsystems for designing and cutting models are used for purposes of 2D design (drafts construction, modeling, modifying patterns, adjusting patterns to corresponding sizes with seam allowances, layout).

At powerful enterprises producing a great number of new models, some definite modules (e.g. layout) can be installed at the workstation of the rate-setter of the material.

CAD-subsystems for designing and cutting models are used for purposes of 3D design. Such modules are an indispensible part of any modern CAD. But these systems are far from being perfect, because creating of a simple and reliable mathematical model transforming a 3D draft into a 2D pattern is not an easy task to do. Nowadays this problem still demands some constructive solution.

Prevailing majority of CAD-programs include the following subsystems:

Construction subsystem makes it possible to build key patterns of the model according to the standard algorithm, or according to a personal algorithm of the user.

The process of creating the models begins with measuring and inputting the necessary model data into the system: assortment, material, primary size, height and seams. If the readymade algorithm is being used, it is important to choose the cutting system. If the user applies their own cutting system, then they should enter corresponding calculation formula and algorithm of primary construction.

Constructive pattern modifying can be performed either by a definite subsystem or by one of its components. Modeling subsystem, as a rule, possesses a line of macro-commands for performing typical operations. These typical operations include: transmitting of tucks, correction of the tuck length, projecting folds, frills, undercuts, parallel and coni-pointed widening; detail separation (projecting relief, yokes etc.); decorating the edge lines of the model (bottom and neck-line).

Subsystem of adding seam allowance makes it possible to build-up technological seams allowances for seams and turn-up, considering the ways of processing and direction of allowance pressing with steam.

Subsystem of pattern size-grading enables automatical creation of a set of patterns of all sizes and heights, presupposed for the model. If the basic model was created with the help of size markers, the system will repeat the process of creation for each definite size. The authors of CAD "Autokroy" called such method of grading "a method of imitational parameter application" [14]. For size gradation of patterns created in a different way, the charts with transmitted key construction points are used.

Layout Subsystem insures the process of quick automated or interactive mode of model layout. Additionally it estimates approximate economic benefits of the layout (such as the width, the length, the area of losses, and rationality coefficient of material use).

The subsystem of sketching is widely used for clothes models visualization. The sketch is created on the basis and with the help of the modules of graphic editors like Paint, Adobe 
PhotoShop, Corel DRAW etc. Some CADs are provided with a special module for creating a 3D sketch on a virtual mannequin, taking into account the texture of the textile material.

\section{RESEARCH METHODS}

To achieve the purpose, a set of following methods has been used: theoretical methods theoretical analysis, synthesis, comparison and matching to characterize the state of problem solving in the academic literature, the study of normative legal documents in the field of education, state standards, curricula, dissertations, electronic resources, scientific work experience of teachers from higher institutions of Ukraine; empirical methods - expert methods (questionnaire) for comparative analysis of CAD clothes; mathematical methods mathematical statistics for the processing of received personal data; calculation of the coefficient of variation to determine the degree of experts' consistency; graphic techniques for illustrating examples of completed tasks.

To substantiate the choice of software for studying at an educational institution in the training of technology teachers and vocational training teachers, a comparative analysis of five CAD clothing has been conducted. For the comparative analysis in this study, the leading world CAD clothing: Optitex, Lectra Systems, Gerber Garment Technology have been selected, as well as local software products CAD Grazia and CAD Julivi.

Requirements for CAD / CAM / CAE systems for studying at an educational institution have been selected in accordance with [15, p. 295-297]. The evaluation has been carried out according to a 3-grade scale: 3 - full compliance with the requirements, 2 - partial compliance with the requirements, 1 - non-compliance with the requirements. The evaluation has been carried out by a group of 8 experts. All experts have higher education in the field of clothing design, practical and educational experience not less than 10 years, work experience with various CAD clothing. Among them there are 3 Doctors of Engineering, 2 Doctors of Education, 3 Doctors of Philosophy. The results of comparative analysis of CAD clothing in terms of expediency of introducing these systems into the educational process of educational institutions are shown in table 1. To assess the degree of experts' coherence, a coefficient of variation has been used when scoring. The coefficient of variation is determined in accordance with [16].

The arithmetic average of software product evaluation is determined by the formula (1).

$$
\bar{x}=\frac{1}{n} \sum_{i=0}^{n} x_{i},
$$

where $\mathrm{x}_{\mathrm{i}}$ is an overall evaluation of the software product by the expert,

$n$ - number of experts.

The average quadratic deviation of the estimates obtained by the software product is determined by the formula (2)

$$
\sigma=\sqrt{\frac{\sum(x-\bar{x})^{2}}{n-1}}
$$

The coefficient of variation is calculated by the formula (3)

$$
V=\frac{\sigma}{\bar{x}} \cdot 100 \%
$$

To investigate the role of automated systems of computer design in the curriculum of Bachelor of Technological Education in Volodymyr Vynnychenko Central Ukrainian State Pedagogical University (Ukraine) we developed and tested the course "Basics of computer 
aided design" (1.5 ECTS credits, 45 academic hours). The course was taught in the eighth semester. It consisted of 45 academic hours divided into 6 hours of lectures, 12 hours of lab work, and 24 hours of self-study, plus 3 hours for consultations. Theoretical block covered the following topics:

Chapter 1. Automated processes of sewing and technical goods design

Theme 1. General CAD characteristics.

Theme 2. CAD software provision

Theme 3. Introduction to the theory and practice of using CAD "Grazia"

Chapter 2. Automated processes of sewing and technical goods production

Theme 4. Technical provision of CAD

Theme 5. Technological equipment with computer management

Theme 6. Effectiveness of introduction and prospects of information technologies use Topics for 1aboratory work are given in Table 1.

Table 1

Thematic coverage for laboratory work in the course "Basics of computer aided design"

\begin{tabular}{|c|l|c|}
\hline № & \multicolumn{1}{|c|}{ Theme } & $\begin{array}{c}\text { Quantity of } \\
\text { hours }\end{array}$ \\
\hline 1 & Designing a draft of a coni-pointed skirt in CAD & 2 \\
\hline 2 & Designing a straight skirt in CAD & 2 \\
\hline 3 & Designing a model and skirt patterns & 1 \\
\hline 4 & Performing layout of a straight skirt in CAD & 1 \\
\hline 5 & Designing a draft of women's trousers in CAD & 4 \\
\hline & Total: & 12 \\
\hline
\end{tabular}

During the course students used automated design program Grazia CAD and a manual by O. Yezhova [17].

Self-study work presupposed the following types of learning activity:

- learning some key aspects of theory;

- doing exercises on building the main elements of drafted drawings (points, intervals, circles, curves);

- reading and preparation for laboratory classes;

- working at students' own design of the outfit.

The following methods of teaching have been used during the course: lectures, practical assignments, building drafts of the details with the help of CAD; construction and analysis of the patterns and details layout; case-method; doing individual tasks on outfit design and construction.

The gradual system of assessment was used during the course, and it consisted of formative, module and summative control. Formative control was applied for assessing laboratory work; module control was represented in a form of module test papers and for assessing individual tasks of a self-study block. Summative control is a final credit mark, calculated in accordance with a 100-point system converted into passing grades.

The students' readiness to use ICT in their professional activity was analyzed in correspondence with the principles of S. Pecherskaja [18]. Thus, the well-defined levels of the students' readiness to use ICT in their professional activity have been identified:

- low - beginner level (student demonstrates unstable interest, in spite ofbeing informed about the role and importance of ICT in designing clothes; is able to perform separate operations with the help of professionally oriented programming 
software, but the student's skills are insufficient for independent realization of professional tasks);

- moderate - level of the user (the student is characterized by a stable interest in ICT in fashion design within the boundaries of the study course; can independently perform typical tasks following detailed instructions, their activity is generally reproductive);

- high - proficient (advanced) user (the student demonstrates stable and strong interest in ICT in fashion design; can easily perform typical tasks as well as use ICT for creating their own projects and design; can estimate effectiveness of ICT in their future professional development; activity is mostly productive).

\section{THE RESULTS AND DISCUSSION}

Table 2 shows the results of a comparative analysis by expert survey of five clothing design programs. The coefficients of variation $\leq 30 \%$ testify to the satisfactory degree of experts' coherence.

Table 2

\section{Comparative analysis of CAD clothing}

\begin{tabular}{|c|c|c|c|c|c|c|}
\hline \multirow[b]{2}{*}{ № } & \multirow[b]{2}{*}{ Criteria } & \multicolumn{5}{|c|}{ CAD Developer } \\
\hline & & $\begin{array}{c}\text { Grazia } \\
\text { (Ukraine) }\end{array}$ & $\begin{array}{c}\text { Julivi } \\
\text { (Ukraine) }\end{array}$ & $\begin{array}{l}\text { Optitex } \\
\text { (Israel) }\end{array}$ & $\begin{array}{l}\text { LectraSystems } \\
\text { (France) }\end{array}$ & $\begin{array}{c}\text { Gerber } \\
\text { Garment } \\
\text { Technology } \\
\text { (USA) }\end{array}$ \\
\hline 1 & Simple and easy to use & 3,00 & 2,75 & 2,00 & 2,13 & 2,00 \\
\hline 2 & $\begin{array}{l}\text { Modernity and } \\
\text { compatibility }\end{array}$ & 2,63 & 2,88 & 3,00 & 2,88 & 3,00 \\
\hline 3 & $\begin{array}{l}\text { Construction of } \\
\text { drawings of garment } \\
\text { details using both their } \\
\text { own design methods and } \\
\text { those pre-set in the } \\
\text { system }\end{array}$ & 3,00 & 3,00 & 1,00 & 1,38 & 1,00 \\
\hline 4 & $\begin{array}{l}\text { Construction of } \\
\text { drawings for individual } \\
\text { and typical figures }\end{array}$ & 3,00 & 3,00 & 1,00 & 1,00 & 1,00 \\
\hline 5 & $\begin{array}{l}\text { Ability to print drawings } \\
\text { on the printer }\end{array}$ & 3,00 & 3,00 & 1,00 & 1,00 & 1,00 \\
\hline 6 & $\begin{array}{l}\text { The interface in } \\
\text { understandable language }\end{array}$ & 3,00 & 3,00 & 1,75 & 1,75 & 1,75 \\
\hline 7 & $\begin{array}{l}\text { Use of the software at } \\
\text { regional enterprises }\end{array}$ & 2,63 & 2,75 & 1,00 & 1,13 & 1,13 \\
\hline 8 & $\begin{array}{l}\text { Education-friendly } \\
\text { software developer's } \\
\text { policy }\end{array}$ & 3,00 & 3,00 & 1,00 & 1,00 & 1,00 \\
\hline 9 & Affordable price & 3,00 & 3,00 & 1,00 & 1,00 & 1,00 \\
\hline & Total score & 26,25 & 26,38 & 12,75 & 13,25 & 12,88 \\
\hline & Coefficient of variation & 2,69 & 4,02 & 5,55 & 9,67 & 4,98 \\
\hline
\end{tabular}

As the Table 2 shows, experts consider all the above programs to be simple enough to master, but the easiest to study are CAD "Grazia" and CAD "Julivi". In this case, only CAD "Grazia" and CAD "Julivi" have sufficient opportunities for use in individual production (p. 3, 4), an understandable language interface, affordable price, are used in most fashion industry 
enterprises of the region, and their developers are friendly to education policy. Thus, according to the results of an expert survey, the indicated criteria are largely consistent with the program of domestic producers - CAD "Grazia" and CAD "Julivi". CAD Optitex has a wide range of design and $3 \mathrm{D}$ visualization of clothing patterns, but the English-language interface and high cost prevent the implementation of these programs in the training of technology teachers and vocational training teachers. At the same time, the program can be recommended for educational institutions of fashion industry.

The benefits of CAD "Julivi" can be attributed to the longer term of using the free demo version ( 2 months), the possibility of free testing of the program by students during the training, the system of discounts for educational institutions, and the widespread use of the system at the enterprises of clothing industry.

In turn, CAD "Grazia" has such strengths as a more modern interface, a convenient arrangement in one window of a drawing and algorithm, application of a system of prompts. The cost of the version for educational institutions, according to the manufacturer on the official site, is about $2 \%$ of the full cost of the system. The developers of the program provide an opportunity for free testing of the program for clothing manufacturers and students during the training.

The results of the conducted approbation have demonstrated that all student participants succeeded in performing their tasks. Students' performed laboratory task samples are given in Figure 2 and Figure 3.

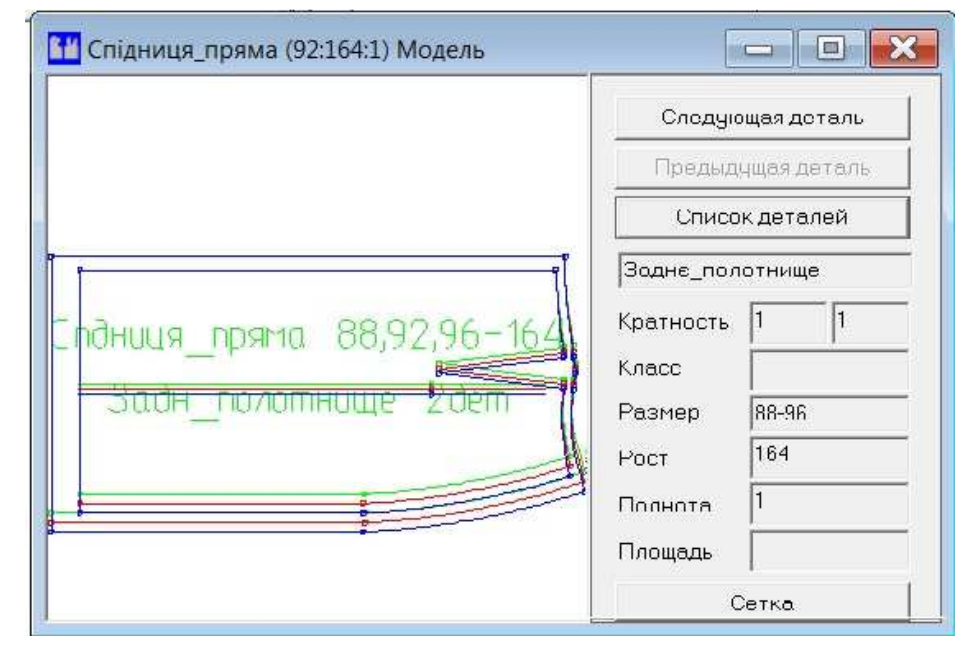

Figure 2. Size gradation of a straight skirt details in Grazia CAD

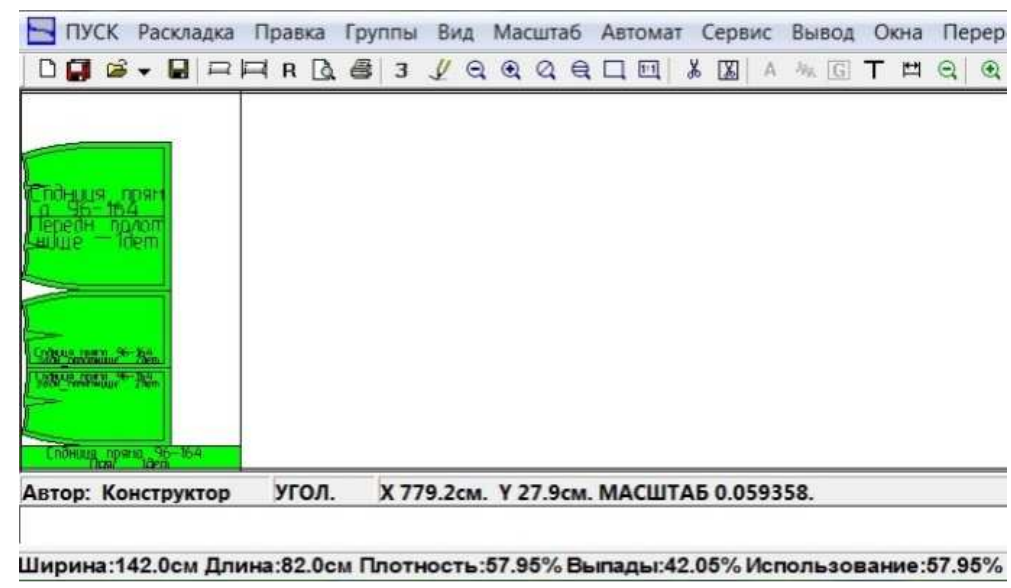

Figure 3.Pattern layout of a straight skirt in Grazia CAD 
According to the results of the summative control at the end of the semester the bachelor students received a certain quantity of credit points (see Table 2 below). As follows from Table 2, students' academic performance was $100 \%$, with the quality coefficient constituting 68,5\%, which meets Ministry of Education and Science of Ukraine accreditation requirements for the educational level of Bachelor.

Furthermore, results of the conducted approbation give grounds to justify effectiveness of the developed course of study together with methodological support of the subject "Basics of computer aided design".

Table 2

\section{Bachelor students' academic end-of-semester achievement results Major "Technological Education" Course "Basics of computer aided design"}

\begin{tabular}{|c|c|c|c|c|}
\hline $\begin{array}{c}\text { Quantity of } \\
\text { points }\end{array}$ & $\begin{array}{c}\text { National } \\
\text { grading system }\end{array}$ & \multirow{2}{*}{ ECTS grading } & \multicolumn{2}{|c|}{ Quantity } \\
\cline { 3 - 5 } & & students & $\begin{array}{c}\text { \% in relation to } \\
\text { the total number }\end{array}$ \\
\hline $90 \ldots 100$ & passed & $\mathrm{A}$ & 2 & 13,3 \\
\hline $82 \ldots 89$ & & $\mathrm{~B}$ & 4 & 26,6 \\
\hline $75 \ldots 81$ & & $\mathrm{C}$ & 4 & 26,6 \\
\hline $67 \ldots 74$ & & $\mathrm{D}$ & 4 & 26,6 \\
\hline $60 \ldots 66$ & & $\mathrm{E}$ & 1 & 0,7 \\
\hline $35 \ldots 59$ & failed & $\mathrm{FX}$ & 0 & 0 \\
\hline $1 \ldots 34$ & & $\mathrm{~F}$ & 0 & $\mathbf{1 0 0}$ \\
\hline Total & & & $\mathbf{1 5}$ & \\
\hline
\end{tabular}

\section{CONCLUSIONS AND PROSPECTS FOR FURTHER RESEARCH}

ICT competence is necessary for trainee technology teachers and vocational education specialists for maintaining proper pedagogical activity with a successful creation of outfit models using computer technology. The introduction to professional-oriented software is realized in higher education institutions of Ukraine in the course of "Basics of computer aided design", after a preparatory course of "Information Technologies".

The paper suggests a systemized list of computer software tools for professional purposes involving the use of automated working space for the designer: tools for correct and safe component management; tools for file creation and file sharing; CAD-subsystems. The list of these software products is systematized in the form of a scheme of an automated designer workstation.

According to the results of an expert survey, the software of domestic producers - CAD "Grazia" and CAD "Julivi" are recommended for introduction into the educational process for trainee teachers of technology and specialists of vocational education.

The results of the conducted approbation in Volodymyr Vynnychenko Central Ukrainian State Pedagogical University (Ukraine) give grounds to justify effectiveness of the developed course of study together with methodological support of the subject "Basics of computer aided design".

The results of the investigation are important for grounding the contents of study for traineeteachers of technology and specialists of vocational education, as well asfor professionals in fashion industry. 
Prospects of further investigation will be aimed at working out a similar methodological support for development of ICT competence of trainee engineers in fashion industry.

\section{REFERENCES (TRANSLATED AND TRANSLITERATED)}

[1] Yu. Doroshenko, I. Birillo, O. Khlyupin, and S. Blashchuk,"Conceptual principles of informational competence of future architects",Informatsiyno-komunikatsiynitekhnologï v suchasniyosviti: dosvid, problemi, perspektivi: ZbirnikMaterialiv III mizhnarodnoïnaukovo-praktichnoïkonferentsiï, pp. 133139,2012. (in Ukrainian)

[2] UNESCO ICT Competency Framework for Teachers. Paris, UNESCO, 2011. [Online]. Available: http://unesdoc.unesco.org/images/0021/002134/213475e.pdf. Accessed on: August 13, 2018. (in English)

[3] L.Fernández-Sanz, J.Gómez-Pérez, andA.Castillo-Martínez, "e-Skills Match: A framework for mapping and integrating the main skills, knowledge and competence standards and models for ICT occupations", Computer Standards \& Interfaces, vol. 51,pp. 30-42,2017. doi:10.1016/j.csi.2016.11.004. (in English)

[4] A.Lukšènienė, B.Žygaitienè, and K.Pošiūnaitè, "IT priemonių taikymo ypatumai per technologij

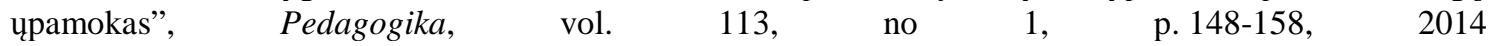
http://www.pedagogika.leu.lt/index.php/Pedagogika/article/view/13/13 (in Lithuanian)

[5] O.V. Yezhova, K.L. Pashkevich, and N.V. Manoilenko, "Comparative analysis of foreign models of fashion education", Revista Romaneasca pentru Educatie Multidimensionala, vol. 10, no 2, pp. 88-101, 2018.doi: 10.18662/rrem/48. (in English)

[6] O.Yezhova, "Formation of ICT competence of future specialists of the garment industry by means of CAD Grazia",Educational Technology \& Society, vol.18.no 3, pp. 410-420,2015. [Online]. Available:http://ifets.ieee.org/russian/depository/v18_i3/pdf/6.pdf. Accessed on: August 13, 2018. (in Russian)

[7] G. Gorghiu, L.M. Gorghiu, and L. Pascale, "Enriching the ICT competences of university students - a key factor for their success as future teachers",Journal of Science and Arts, no1, pp. 183-190, 2018. (in English)

[8] N.V. Morze, and O.P. Buinytska, "Raising information and communication technologies competence of scientific and pedagogical employees - a key requirement of the quality of educational process", Information Technologies and Learning Tools, vol. 59, no. 3, pp. 189-200, june 2017. [Online]. Available at: https://journal.iitta.gov.ua/index.php/itlt/article/view/1667/1184. Date accessed: August 13, 2018. (in Ukrainian)

[9] F. Chen, N. V.Gorbunova, A. R. Masalimova, and J. Birova, "Formation of ICT-Competence of Future University School Teachers", Eurasia Journal of Mathematics Science and Technology Education, vol. 13,no. 8,pp. 4765-4777, 2017. doi: 10.12973/eurasia.2017.00963a.(in English)

[10] K. Peter, A. Hašková, M.Palaj, M. Skačan, and J. Záhorec, "How to Teach CAD/CAE Systems",International Journal of Engineering Pedagogy (iJEP), vol. 8,no. 1,pp. 148-162, 2018. doi: 10.3991/ijep.v8i1.8185. (in English)

[11] B. Barbero, C. Pedrosa, and R. Samperio, "Learning CAD at university through summaries of the rules of design intent", International Journal of Technology and Design Education, vol. 27, no. 3, pp. 481-498, 2017. doi: 10.1007/s10798-016-9358-z. (in English)

[12] C. Yan,B. Yu,Y.Hui, andF.Zhou, "CAD Education of College Students with Engineering Practice and Team Work", Eurasia Journal of Mathematics, Science and Technology Education, vol. 13., no. 8., pp. 5569-5576,2017.doi: 10.12973/eurasia.2017.01010a. (in English)

[13] Program «3D-modeling» [Online]. Available: http://julivi.com/3d\%D0\%BC\%D0\%BE\%D0\%B4\%D1\%83\%D0\%BB\%D1\%8C.html. Accessed on: August 13, 2018. (in Russian)

[14] Technical multiplication [Online]. Available: http://autokroy.com/content/o-produkte. Accessed on: August 13, 2018. (in Russian)

[15] O. Yezhova, "Theory and practice of creating predictive models for training skilled workers in the sewing industry“", Kirovohrad, 2016.(inUkrainian)

[16] S.D. Beshelev,andF.G. Gurvich, "Mathematical and statistical methods of expert estimates". Moscow: Statistika, 1980. (in Russian)

[17] O. Yezhova, "Information technology in the creation of garments",Kirovohrad, 2015. (inUkrainian)

[18] S. Pecherskaja, "Theoretical and methodological bases of readiness of students to the use of information technology ”, avtoref. diss. ... dokt.psih.nauk: spec. 19.00.07 «Pedagogicheskajapsihologija»,Sochi, 2007. (in Russian) 


\title{
ФОРМУВАННЯ ІКТ-КОМПЕТЕНТНОСТІ МАЙБУТНІХ ФАХІВЦІВ ТЕХНОЛОГІЧНОЇ ОСВІТИ У НАВЧАННІ СИСТЕМ АВТОМАТИЗОВАНОГО ПРОСКТУВАННЯ ОДЯГУ
}

\author{
Сжова Ольга Володимирівна \\ доктор педагогічних наук, кандидат технічних наук, \\ доцент кафедри теорії і методики технологічної підготовки, охорони праці та безпеки життєдіяльності \\ Центральноукраїнський державний педагогічний університет імені Володимира Винниченка, \\ м. Кропивницький, Україна \\ ORCID ID0000-0002-5920-1611 \\ oyezhova70@gmail.com
}

\author{
Пашкевич Калина Лівіанівна \\ доктор технічних наук, професор кафедри ергономіки та проектування одягу \\ Київський національний університет технологій та дизайну, м. Київ, Україна \\ ORCID ID 0000-0001-6760-3728 \\ kalina.pashkevich@gmail.com
}

\section{Гринь Денис Васильович}

кандидат технічних наук, старший викладач кафедри теорії і методики технологічної підготовки, охорони праці та безпеки життєдіяльності

Центральноукраїнський державний педагогічний університет імені Володимира Винниченка, м. Кропивницький, Україна

ORCID ID 0000-0002-5625-7812

dvgrinj@gmail.com

\begin{abstract}
Анотація. Стаття присвячена проблемі формування готовності до застосування програмного забезпечення систем автоматизованого проєктування (САПР) одягу майбутніми вчителями технологій та педагогами професійної освіти. Відзначено, що для розвитку індустрії моди фахівці повинні володіти як основами інформаційних технологій, так і основами застосування САПР одягу. ІКТ-компетентність необхідна вчителям технологій та педагогам професійної освіти як для провадження професійної діяльності, так i для успішного створення моделей одягу з застосуванням комп'ютерної техніки. Метою дослідження є обгрунтування переліку програмного забезпечення для вивчення вчителями технологій та педагогами професійної освіти з метою застосування САПР у професійній діяльності. Професійно орієнтовані програми вивчаються в закладах вищої освіти при вивченні предмету «Основи систем автоматизованого проектування», а готовність до їх опанування формується в процесі вивчення дисципліни «Інформаційні технології».

В індустрії моди інформаційні технології застосовуються для створення нових моделей, керування обладнанням, а також керування життєвим циклом виробів. Систематизовано перелік комп'ютерних програм, які повинен уміти застосовувати фахівець для виконання професійних завдань $з$ використанням автоматизованого робочого місця конструктора: програми для коректного та безпечного керування компонентами системи; для створення документів; для обміну інформацією; САПР-підсистеми. Схарактеризовано програму дисципліни «Основи систем автоматизованого проектування». Проведено апробацію, яка засвідчила ефективність розробленої програми і методичного забезпечення предмету «Основи систем автоматизованого проектування». Результати дослідження важливі для обгрунтування змісту освіти майбутніх учителів технологій та педагогів професійної освіти, а також фахівців індустрії моди.
\end{abstract}

Ключові слова: САПР; ІКТ-компетентність; програмне забезпечення; дизайн; індустрія моди; освіта. 


\title{
ФОРМИРОВАНИЕ ИКТ-КОМПЕТЕНТНОСТИ БУДУЩИХ СПЕЦИАЛИСТОВ ТЕХНОЛОГИЧЕСКОГО ОБРАЗОВАНИЯ ПРИ ИЗУЧЕНИИ СИСТЕМ АВТОМАТИЗИРОВАННОГО ПРОЕКТИРОВАНИЯ ОДЕЖДЫ
}

\author{
Ежова Ольга Владимировна \\ доктор педагогических наук, кандидат технических наук, доцент кафедры теории и методики \\ технологической подготовки, охраны труда и безопасности жизнедеятельности \\ Центральноукраинский государственный педагогический университет имени Владимира Винниченко, \\ г. Кропивницкий, Украина \\ ORCIDID0000-0002-5920-1611 \\ oyezhova70@gmail.com
}

\author{
Пашкевич Калина Ливиановна \\ доктор технических наук, профессор кафедры эргономики и проектирования одежды \\ Киевский национальный университет технологий и дизайна, г. Киев, Украина \\ ORCID ID 0000-0001-6760-3728 \\ kalina.pashkevich@gmail.com
}

\section{Гринь Денис Васильевич}

кандидат технических наук, старший преподаватель кафедры теории и методики

технологической подготовки, охраны труда и безопасности жизнедеятельности

Центральноукраинский государственный педагогический университет имени Владимира Винниченко,

г. Кропивницкий, Украина

ORCID ID 0000-0002-5625-7812

dvgrinj@gmail.com

\begin{abstract}
Аннотация. Статья посвящена проблеме формирования готовности к использованию программного обеспечения САПР одежды будущими учителями технологий и педагогами профессионального образования. Отмечено, что для развития индустрии моды специалисты должны владеть как основами информационных технологий, так и основами использования САПР одежды. ИКТ-компетентность необходима учителям технологий и педагогам профессионального образования как для осуществления педагогической деятельности, так и для успешного создания моделей одежды с использованием компьютерной техники. Целью исследования является обоснование перечня программного обеспечения для изучения учителями технологий и педагогами профессионального образования с целью использования САПР в профессиональной деятельности. Профессиональноориентированные программы изучаются в заведениях высшего образования при изучении предмета «Основы систем автоматизированного проектирования», а готовность к их изучению формируется в процессе изучения дисциплины «Информационные технологии». В индустрии моды информационные технологии используются для создания новых моделей, управления оборудованием, а также для управления жизненным циклом изделий. Систематизирован перечень компьютерных программ, которые должен уметь использовать специалист для выполнения профессиональных задач с использованием автоматизированного рабочего места конструктора: программы для корректного и безопасного управления компонентами системы; для создания документов; для обмена информацией; САПР-подсистемы. Охарактеризована программа дисциплины «Основы систем автоматизированного проектирования». Проведенная апробация показала эффективность разработанной программы и методического обеспечения предмета «Основы САПР». Результаты исследования важны для обоснования содержания обучения будущих учителей технологий и педагогов профессионального образования, а также специалистов индустрии моды.
\end{abstract}

Ключевые слова: САПР; ИКТ-компетентность; программное обеспечение; дизайн; индустрия моды; образование.

\section{(c) $\mathrm{BY}-\mathrm{NC}-\mathrm{SA}$}

This work is license dun der Creative Commons Attribution-Non Commercial-Share Alike 4.0 International License. 